\title{
BEEF SPECIES SYMPOSIUM: Economic considerations related to U.S. beef herd expansion ${ }^{1}$
}

\author{
G. T. Tonsor*2 and L. L. Schulz $\uparrow$ \\ *Department of Agricultural Economics, Kansas State University, Manhattan 66506; \\ and $\dagger$ Department of Economics, Iowa State University, Ames 50011
}

\begin{abstract}
Significant attention perpetually surrounds possible changes in breeding herd inventories in the U.S. beef cattle industry. This article outlines economic considerations of U.S. herd expansion. Factors restricting expansion include land availability, increasing production efficiency, operator demographics, capital requirements, and commodity price volatility. Several offsetting factors support herd expansion including unprecedented cow-calf returns, ongoing global beef demand growth, and timing within the current cattle cycle. In addition to these industry-wide
\end{abstract}

factors, several important variations in individual ranch considerations are outlined. The authors' expectations on future herd dynamics are provided, highlighting broader implications for individual operations, industry leaders, and the entire beef-cattle supply chain. The substantial economic impact and importance of the cow-calf sector warrants broader appreciation of these economic factors impacting herd expansion. The future size of the U.S. cattle industry is determined by the individual decisions of over 70,000 cattle owners, making this issue worthy of review by all industry stakeholders.

Key words: beef cattle, demand, economics, heifer retention, herd expansion, replacement females

(C) 2015 American Society of Animal Science. All rights reserved. $\begin{array}{r}\text { J. Anim. Sci. 2015.93:4227-4234 } \\ \text { doi:10.2527/jas2014-8473 }\end{array}$

\section{INTRODUCTION}

Beef cattle production in the United States is a vertically connected system that spans from cow-calf operations producing feeder cattle for the nation's stocker and feedlot operations, which combine to feed cattle to heavier weights for eventual slaughter. Retail beef supplies are heavily dependent on cow-calf production decisions, namely the retention of heifers as replacements and the holding of cows for further breeding service, as these decisions dictate the size of subsequent calf crops (Schmitz, 1997). As Melton (1980, p. 137) states "probably no single aspect of modern beef herd management is as complicated, or has as potentially great an economic impact, as the cow culling and replacement decision.” Buhr and Kim (1997) illustrate how changes throughout the industry are associated

\footnotetext{
${ }^{1}$ Based on a presentation at the Beef Species Symposium (session 1) titled "The U.S. stocker and feedlot industries" at the Joint Annual Meeting, July 20-24, 2014, Kansas City, MO.

${ }^{2}$ Corresponding author: gtonsor@ksu.edu

Received September 4, 2014.

Accepted December 18, 2014.
}

with significant and vertically connected adjustment costs. For instance, breeding herd expansion decisions directly influence the volume of transactions at auction markets and the number of calves available for feeding in commercial feedlots and processing by packing plants as well as cow and bull slaughter numbers. In short, the beef cow herd is the foundation of the total cattle inventory, and the economic vitality and size of this sector is essential to the entire U.S. beef industry.

Given its importance to the entire beef-cattle industry and broader economy, significant attention and discussion perpetually surround the issue of possible changes in breeding herd inventories in the United States. The main purposes of this article are to outline economic considerations of beef cow herd expansion, summarize implications for individual operations, and synthesize our expectations regarding the direction of future breeding herd dynamics.

\section{HISTORICAL PERSPECTIVE AND FACTORS CONSTRAINING EXPANSION}

It is useful to start by taking stock of historical patterns and factors that have led the industry to its cur- 


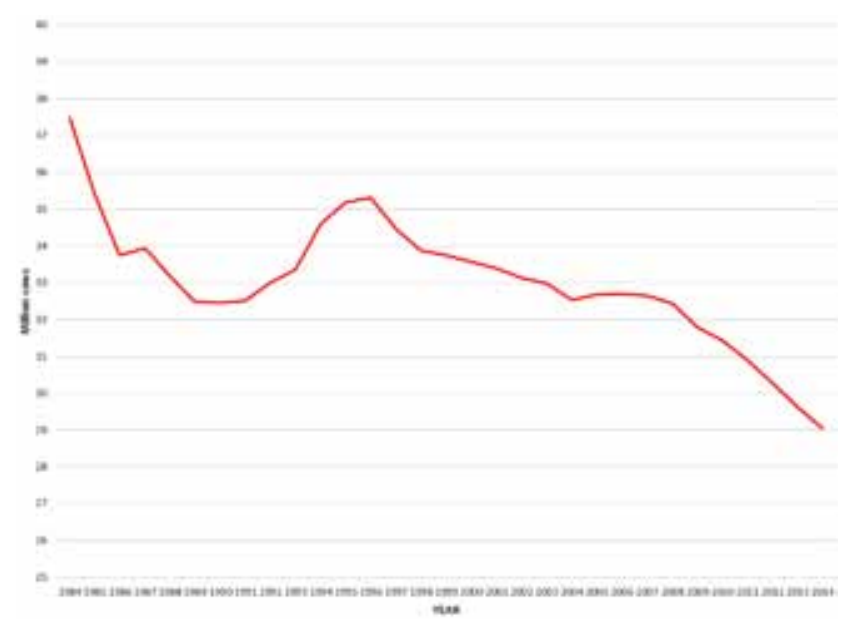

Figure 1. January 1 total beef cow inventory. This figure presents U.S. beef breeding inventories (million beef cows) on January 1 of each year from 1984 to 2014. Source: Livestock Marketing Information Center (2014).

rent situation. As shown in Fig. 1, the U.S. beef cow herd entered 2014 at a historically low level of just above 29 million animals compared with about 35 million animals in the mid 1990s and well over 35 million animals in the early 1980s. As beef demand decreased throughout the 1980s and 1990s, profitability at the cow-calf level fell, leading to a long period of inventory reduction (Marsh, 1999). By 2014, one of the longest and most severe liquidation phases in the industry's history reduced the U.S. beef cow herd to its lowest level since 1962 (USDA NASS, 2014a). This reduced breeding herd has led to lower calf crops and subsequently tighter cattle and beef supplies throughout the industry. More recently, a significant period of retail beef demand growth has reinforced economic viability of possible herd growth (Tonsor, 2014b). Furthermore, the volume of U.S. beef going to export markets has been more resilient than what some would expect and export demand for U.S. beef remains strong (Meyer and Steiner, 2014).

The combination of tighter supplies and improved beef demand has initiated a period of unprecedented profitability for the cow-calf industry. As shown in Fig. 2, expected cow-calf returns for 2014 and 2015 exceed US $\$ 400 /$ cow when, previously, returns over cash cost greater than $\$ 100$ characterized very favorable years. The ultimate question becomes, given the uncertainty experienced the last several years, what level of return will be required to encourage producers to begin rebuilding the cow herd? In other words, what level of annual return would motivate producers to assume risk in retaining more heifers and/or investing in additional cows? It is important to realize that the uncertainty experienced during the last several years has likely increased the expected return needed to trigger industry-wide expansion.

Despite improved returns for cow-calf producers, herd expansion has yet to be realized. There is a

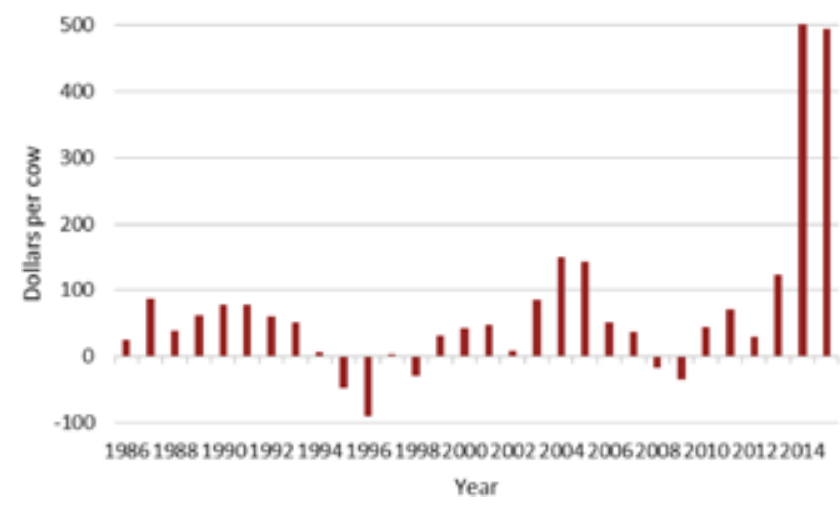

Figure 2. Estimated annual average cow-calf returns over cash cost. This figure presents estimated returns over cash costs (dollars/cow) for each year from 1986 to 2013. Projected returns over cash costs (dollars/ cow) for 2014 and 2015 are also presented. Source: Livestock Marketing Information Center (2014).

lengthy list of suspected reasons for this, reinforcing the need to provide corresponding economic context. This partially complete list includes weather, land availability, productivity gains, producer age, capital requirements, and price volatility.

Drought in the Southern Plains in 2011 and much of the United States in 2012 and 2013 further delayed expansion, as the required forage to maintain, much less expand, existing inventories was not available in several key cow-calf production regions. To highlight the impact on herd inventories, note Livestock Marketing Information Center (2014) estimates that $41,76,31$, and $5 \%$ of cows resided in early August of 2011 to 2014, respectively, in states with at least $40 \%$ of their range and pasture hectarage in poor or very poor condition. The fact that one-third to three-fourths of cows were in areas of stressed land base conditions in the 2011 to 2013 period clearly illustrates why net national expansion would have been difficult and ultimately was not realized over this period.

Beef cow-calf operations are primarily tied to land suitable for grazing cattle, with limited ability to substitute capital for land, which has occurred in other sectors to facilitate large-scale production by moving animals into confinement facilities. Largely in response to a multiyear period of abnormally positive returns for crop producers, significant hectarage has transitioned out of pasture to alternative uses. This decrease in land available for grazing beef cows or producing needed forage is also regularly noted as restricting expansion. A comparison of the 2007 and 2012 Census of Agriculture shows that total pasture hectarage in the United States declined by $3.6 \%$ (USDA NASS, 2014b). Total pasture hectarage in the United States consists of permanent pasture and range, woodland pasture, and cropland used as pasture. Cropland used as pasture represents the buffer or interface between crop and forage production in the United 
States, because it can be switched from pasture to crop production if relative crop and forage values change. The conversion of pastured cropland to crop production can be accomplished relatively easily, but because it is quite costly to return cropland to pasture, it usually reflects a longer-term (more than year to year) decision about land use (Peel, 2014). Cropland used for pasture decreased from 14.49 million ha in 2007 to 5.18 million ha in 2012, a 64\% decrease (USDA NASS, 2014b). Bobst and Davis (1987) estimate that for each additional million hectares that are reallocated from pasture to cropland, the total number of beef cows in inventory declines by 14,786 . Given the magnitude of land conversion in areas such as the eastern half of the country (i.e., Midwest, Great Lakes, Appalachian, Gulf, and Southeast regions), 21\% of total pasture land in 2007 decreased to less than 7\% in 2012 (USDA NASS, 2014b); this presents a constraint to the amount of herd expansion that may occur both nationally in aggregate and more acutely in some regions.

Economists expect ongoing increases in productivity throughout an industry to temper the rate of herd increases. For instance, Marsh (1999) estimates that for each 1\% increase in breeding stock productivity, there is a $2.4 \%$ reduction in long-run beef cow inventories. This finding reflects the fact that fewer cows are needed to hit a given beef production target, as each cow results in an increasing amount of beef production. The implication of this is that a smaller herd size than experienced in past cattle cycles (Fig. 3) is likely needed without substantial beef demand growth (Tonsor, 2011). However, how large inventories can and will expand largely depends on growth in domestic and export beef demand.

Demographic adjustments including increasing producer age and off-farm employment are noted as constraining interest in expansion. The 2012 Census of Agriculture indicated that $35 \%$ of beef cattle and ranching principal operators are over age 65 and there are 6 times more principal operators over 65 than under 35 (USDA NASS, 2014b). As an operation manager or owner ages, he or she typically becomes more conservative and may be more likely to use shorter-term horizons in assessing investment opportunities. In addition, principal operators having an occupation off-farm may represent operations that lend themselves better to off-farm work and constrain interest in expansion due to time available and/or the financial need to expand. Sixty-five percent of beef cattle and ranching principal operators worked at least $1 \mathrm{~d}$ off the farm, and $44 \%$ worked $200 \mathrm{~d}$ off the farm (USDA NASS, 2014b).

The sheer level of cattle prices throughout the industry corresponds with unprecedented amounts of capital being required to maintain a cow-calf herd. In addition, high asset values make the capital requirements unreachable for many young producers and

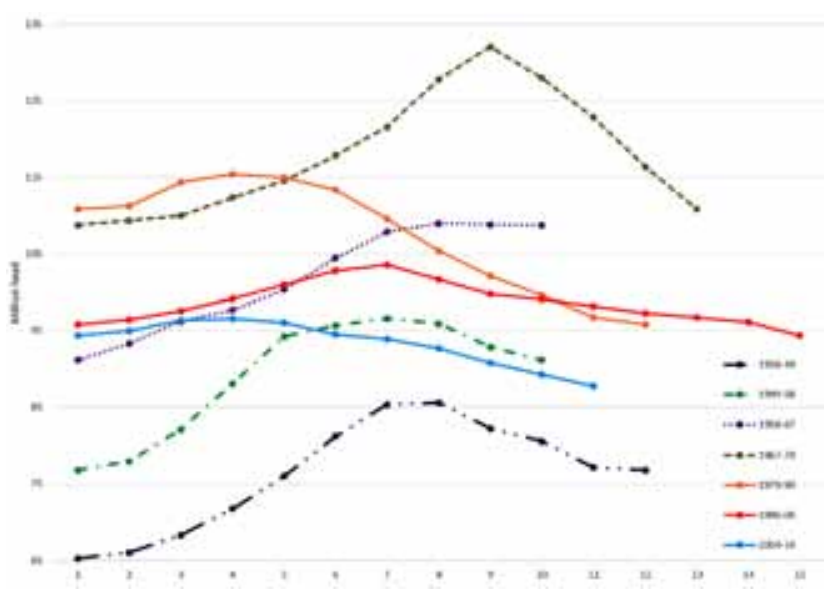

Figure 3. Historical total cattle inventories and cycles. This figure presents total U.S. cattle inventories (million animals) on January 1 of each year from 1938 to 2014. Separate lines are provided for each estimated cattle cycle. Source: Livestock Marketing Information Center (2014).

newer operations with limited equity and financial resources. Combined with recent periods of increased input and output price variability, this "new price environment" has likely altered the risk-reward relationship some producers have in considering expansion. If one considers most producers as being adverse to risk and uncertainty, for a given level of expected profit, economists anticipate fewer investments to be made in settings viewed as more variable.

To summarize the impact of these and other factors on expansion, consider a rule of thumb that positive returns of about $\$ 100 /$ cow for cow-calf producers lead to herd expansion. This simplistic rule may have held in the past when examining past profitability and herd size patterns. However, in today's industry environment, this rule seems highly unlikely to hold. To illustrate this, note how $\$ 100 /$ cow now represents a much lower return on investment as the annual cost of maintaining a cow has increased in recent years. Specifically, a $\$ 100$ return when incurred with annual operating costs below $\$ 1,000 /$ cow, which was the case between 1996 and 2003 , presents a much more appealing return on investment than $\$ 100 /$ cow when total costs exceed $\$ 1,200$ / cow as in 2011 through 2013 (USDA ERS, 2014a).

Beyond the reduced mean return on investment component that is most frequently discussed in the industry, the general volatile and uncertain environment may have changed from the perspective of many producers. Specifically, producers have taken full note of how volatile feedstuff prices have been in recent years. Moreover, the broader geopolitical uncertainty on a global stage, domestic political and regulatory uncertainty, and debates that persist internally within and across industry segments all combine to a net increase in uncertainty regarding prospects for profitability in upcoming years. 
In economist-speak, if either mean return on investment declines or the associated levels of investment volatility and uncertainty increase, then less herd expanding investments are expected. When both adjustments occur, as in the U.S. beef industry, expansion will be significantly constrained compared with alternative environments characterized by greater mean returns or reduced volatility and uncertainty. Stated differently, the risk-reward relationship producers see in making herd expansion investments may well have changed, leading to the current situation of limited or no herd expansion.

It is also important to note existing research highlighting the relative role of production cost on profitability of cow-calf operations. Dhuyvetter and Herbel (2013) estimate there is a 0.33 correlation between gross income and profit of cow-calf operations. Although it is widely recognized that firms with greater gross incomes (primarily reflecting higher prices, sales weights, and weaning rates) are more profitable, comparing this with the impact of costs is critical. Dhuyvetter and Herbel (2013) estimate there is a -0.82 correlation between total cost and profit, clearly highlighting that total costs have a much greater impact on profit than gross income for cow-calf operations. Consistent with this, it is important to note that several authors have found evidence of economies of size (i.e., decreasing costs as size of operation increases) in beef cow-calf production (Boggs and Hamilton, 1997; Langemeier et al., 2004; Ramsey et al., 2005). McBride and Mathews (2011) show that significant economies of size are achieved by moving from the 20- to 49-cow herd size to the 50- to 99-cow herd size. Between the 50- to 99-cow and 200- to 499-cow herd sizes, operating and operating plus capital costs per cow are much the same for the 3 size groups. Total economic costs, primarily due to charges for unpaid labor, reveal economies of size across all size groups, and the largest farms (500 cows) have significantly lower costs per cow than all other farms. Capital and labor costs are much less on larger operations because they are able to spread fixed units of these resources over greater production. As noted below, the key implication of this for herd expansion is that larger operations are likely to have favorable production cost structures and, hence, be better positioned to pay higher prices for replacement females.

\section{FACTORS SUPPORTING EXPANSION}

Up to this point, reasons for limited expansion have been presented. This section turns to outlining factors supportive of additional herd expansion. The list of suspected reasons for herd expansion to be imminent includes profitability, beef demand growth, and inventory cycle dynamics.
As noted earlier (Fig. 2), cow-calf returns in 2014 and 2015 are forecasted to be nearly 3 times better than the previously viewed "good years" of 2004, 2005, and 2013. Most economists consider the cowcalf industry to operate like a textbook example of a commodity industry where long-run economic (not accounting) profits are zero. The main implication of this is that the current and upcoming profit levels are expected to lead cow-calf producers to "bid away" margins in the form of buying (and/or retaining) replacement females to expand their herd, making land investments to increase their herd carrying capacity, etc. These adjustments, in time, are expected to return the cow-calf sector to more typical levels of profitability, increasing breeding inventories in the process.

The United States is the world's largest producer of beef and the world's largest consumer of beef in terms of total kilograms. In 2013, beef and beef variety meat exports amounted to 1,172,792 t (2.6 billion pounds) worth $\$ 6.2$ billion. Approximately $13.2 \%$ of U.S. beef and variety meat production was exported in 2013 (USMEF, 2014). Over the next $10 \mathrm{yr}$, global meat consumption is projected to grow by $1.9 \%$ annually with exports of beef projected to rise even quicker at a rate of $2.8 \% / \mathrm{yr}$ (USDA ERS, 2014b). This growth in beef demand results from an increasing population, rising per capita incomes, changes in consumer preferences, and improvements in product characteristics such as convenience, tenderness, food safety, health, nutrition, etc. (Schroeder et al., 2013). The projection of beef exports to grow faster than base consumption presents a favorable opportunity to major beef exporters. To capitalize on current and expected beef demand strength, many analysts indicate the United States needs to increase overall beef production, which is inherently initiated by expanding breeding herds.

Feeder cattle prices are affected by prices paid for slaughter cattle, which, in turn, are affected by consumer demand for beef as reflected in retail beef prices. Cow-calf producers respond to high (or low) feeder cattle prices by increasing (or decreasing) production, but biological constraints of cattle prevent producers from instantly responding to price. This gives rise to the cattle cycle: cyclical increases and decreases in the cattle herd over time determined by the combined effects of cattle prices; the time needed to breed, calve, and raise cattle to market weight; and climatic conditions (USDA ERS, 2010; McBride and Mathews, 2011). Figure 3 provides a summary of past cattle inventory cycles demonstrating how past cycles have lasted 9 to $14 \mathrm{yr}$. Because the current cycle is entering its 11 th year, some analysts believe this signals herd expansion is imminent. Tonsor (2011) provides an overview of how cattle cycles have changed over 


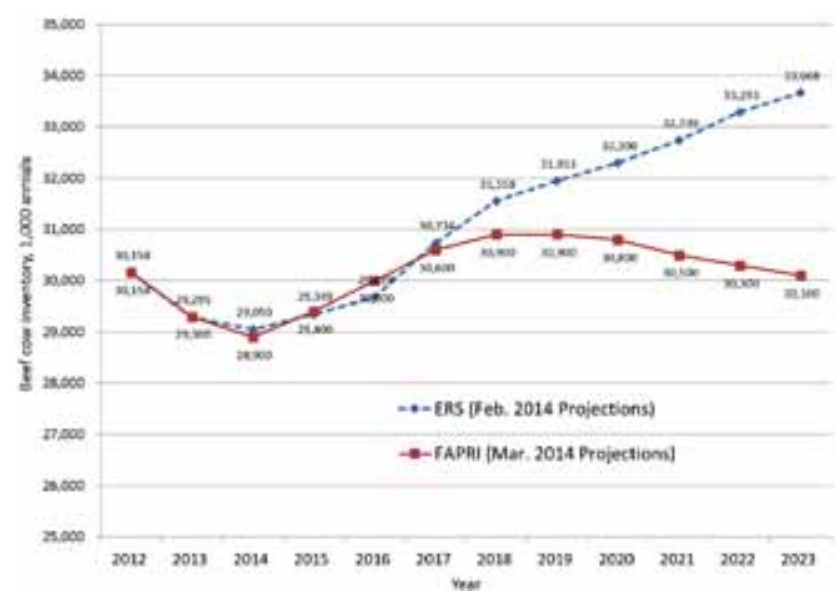

Figure 4. Projected beef cow inventories. This figure presents 2 alternative projections for U.S. beef cow inventories for 2015 to 2023. The USDA Economic Research Service (ERS; 2014a) projections were released in February of 2014 and the Food and Agricultural Policy Research Institute (Food and Agricultural Policy Research Institute, 2014) projections were released in March of 2014. Source: USDA Economic Research Service (2014a) and Food and Agricultural Policy Research Institute (2014).

time, noting that the variation in inventories has declined over time, which indicates the magnitude of expansion once initiated may be less than experienced in the past (or expected by some industry stakeholders).

Given these reasons for possible herd expansion to be pending, it is useful to characterize the varied views on how much expansion may occur by comparing 2 different forecasts (Fig. 4). The USDA Economic Research Service (2014a) in February of 2014 released projections of $16 \%$ herd growth between 2014 and 2023 (33.67 million animals in total by 2023). Conversely, the Food and Agricultural Policy Research Institute (2014) published projections in March of 2014 of the herd in 2023 being only 4\% larger than in 2014 (30.10 million animals in total by 2023). The difference in these economic projections and the broader uncertainty of aggregate industry expansion is only magnified at the individual level. That is, the list of possible reasons for expansion or contraction is extensive across a group as heterogeneous as the U.S. cow-calf sector. This, coupled with the well-noted importance of this sector to the vitality of the entire U.S. beef industry, leads our assessment to the next section focused on individual operation considerations.

\section{INDIVIDUAL, RANCH-LEVEL CONSIDERATIONS}

An online survey of BEEF Magazine subscribers (largely cow-calf producers) was conducted in July and August of 2014 with a total of 1,003 completed surveys. This survey provides insights regarding current expansion plans of producers. Some key findings include that $19 \%$ of respondents plan to expand their herd by over
$11 \%$ and another $52 \%$ plan to expand by $10 \%$ or less. Among those planning to expand, $84 \%$ plan to hold back heifers, $37 \%$ plan to buy replacements, and $13 \%$ plan to sell fewer cull cows. These responses signal a host of points key to individual herd expansion decisions and underlying industry heterogeneity.

As cattle producer interest in possible beef herd expansion grows, it is important to recognize what resources are available to guide these investment decisions and to appreciate key variables that drive expected investment returns. Sensitivity analyses regularly highlight the critical role of production costs, investment returns being targeted, and expectations regarding future cattle prices. Producers are highly heterogeneous in these and other characteristics, which, in turn, magnifies the range of interest in herd expansion, varied approaches to accomplish expansion, etc. This situation is precisely the reason existing decision support tools regarding beef herd expansion have been developed and are regularly updated. For instance, available resources include partial budgets for assessing if an operation should buy or raise heifers and net present value (NPV) analyses to estimate what price an operation can consider paying for a given targeted rate of return.

One of these resources (KSU-Beef Replacement) is an Excel spreadsheet that evaluates the economic situation presented by a given producer purchasing an available replacement female for their breeding herd. (This spreadsheet and video tutorial are available at http://www.agmanager.info/Tools/default. asp\#LIVESTOCK.) When it comes to projecting the NPV offered by purchasing a replacement female, a number of assumptions about the future must be made providing key inputs into this decision aide. Tonsor and Dhuyvetter (2013) highlight key sensitivity analysis drivers using the resource. Specifically, the authors show how $10 \%$ changes in the annual cost of an operation to maintain a cow, discount rate used in the investment decision, and projected feeder cattle prices each impact the NPV of a replacement female. As expected, operations with lower operating costs, charging lower discount rates, and expecting higher future cattle prices are positioned to pay higher prices for beef replacements. The notable heterogeneity that exists across cow-calf operations in production cost situations, the return on investment they consider acceptable, and expectations on future cattle prices underlies why some producers are eagerly interested in expanding their operations whereas other operations are not.

To provide an updated example of this heterogeneity, note that the $K S U$-Beef Replacement resource was most recently updated in February of 2014 using a default situation based on projected cattle prices provide at that time by the USDA Economic Research Service, annual cow costs of $\$ 700$, and a discount interest rate of $7.5 \%$. 
Using these default values, the NPV of replacement heifers expected to provide calves over the next $7 \mathrm{yr}$ is $\$ 2,085$. If a producer in this base situation paid more (or less) than this, he or she effectively would be initiating an investment with an expected rate of return less (or more) than $7.5 \%$. To illustrate the impact of production costs, note how reducing annual cow costs to $\$ 500$ from the base value of $\$ 700$ increases the NPV to $\$ 2,863$ consistent with the fact that each calf yields a greater net return per year facilitating operations with lower annual costs to pay more for replacements. Conversely, adjusting the base case from a discount rate of 7.5 to $15.0 \%$ reduces the NPV to $\$ 1,767$, highlighting how producers more concerned with increased volatility and uncertainty may be less aggressive in expansion. Finally, increasing expected output (calf and cull cow) prices by 5\% increases the NPV to $\$ 2,328$, reflecting more optimistic future profitability expectations. These scenarios clearly illustrate how varied cost structures, heterogonous comfort with the risk environment of herd expansion, and diverse views on future cattle prices each notably impact NPV assessments leading to assorted interest and ability to expand herds of individual operations.

Selecting the most economical source of replacement females may be one of the more important decisions confronting a cow-calf producer as this decision has major implications for effectively using resources, controlling costs, and long-run business viability. As indicated by the BEEF Magazine survey, producers use heifer retention and purchasing of external females to expand their breeding herd. The USDA Animal and Plant Health Inspection Service indicates that $83 \%$ of operations expand by retaining and raising their own heifers (USDA APHIS, 2008). Whether to use raised or purchased replacements can be a complex issue, because each alternative has both advantages and disadvantages. To assist producers in making this "raise vs. buy" decision, Iowa State University Extension and Outreach has developed 2 partial budget spreadsheets to determine which management strategy is best in any given year. (These spreadsheets and video tutorial are available at http://www.iowabeefcenter.org/heiferdevelopment. html.) The first spreadsheet, Buying Heifers for Beef Cow Replacement, considers the returns and costs that will change if replacement heifers are purchased rather than raised from within the herd. The second spreadsheet, Raising Heifers for BeefCow Replacement, considers the returns and costs that will change if replacement heifers are raised from within the herd rather than purchased. Economic effects are specified on a per-animal basis over the period of time between the decision to retain or sell a weaned heifer calf and when a purchased replacement heifer would arrive at the ranch.
Although most producers raise herd replacements, purchasing replacements sometimes can be an attractive alternative. To illustrate this using the Buying Heifers for Beef Cow Replacement spreadsheet to analyze whether to continue raising replacements or purchase them, consider the following example based on December 2013 market conditions. A cow-calf operation has 100 beef cows and needs about 20 replacement heifers annually to maintain the herd. The producer is considering selling raised heifer calves at weaning time and buying pregnant heifers at $22 \mathrm{mo}$ of age ( 2 mo before calving). Heifer calves average $239 \mathrm{~kg}(525 \mathrm{lb})$ per animal at 6 mo of age and can be sold for $\$ 3.74 / \mathrm{kg}(\$ 1.70 / \mathrm{lb})$, net of selling costs. The interest rate is $4 \%$, which is based on the returns realized from the investment of returns (or reduction in borrowing) from the sale of the heifer calves. The feed, nonfeed, and fixed costs assumed for a heifer raised during the 16-mo period between weaning and the arrival of a purchased heifer on the farm are $\$ 568.00, \$ 272.09$, and $\$ 223.30$ per animal, respectively. It is assumed that a bred heifer at 22 mo of age can be purchased for $\$ 1,950$ per animal, net of purchase costs (e.g., transportation). Using this information, a producer can determine if buying replacement heifers will increase farm net income.

For added returns, the example cow-calf producer expects to realize $\$ 940.10$ if the heifer calf is sold and a replacement heifer is purchased 16 mo later. Those returns stem from the sale of the heifer calf at weaning (\$892.50) and interest earned or saved on that amount, assuming an annual rate of $4 \%$ and 16 mo (\$47.60). The producer estimates there will be no increase in genetic improvement if heifers are purchased; if there were any multiyear gain in genetics, added returns would increase. For reduced costs, by purchasing a replacement, the producer eliminates the cost of raising a heifer replacement during the 16-mo development period. These cost reductions add to $\$ 1,063.39$ /animal. Included in the cost savings are feed, nonfed, and fixed costs. The total added returns from buying rather than raising replacements is the sum of the added returns and reduced costs, $\$ 2,003.49$ per animal. Turning to the total added costs, the only added cost projected by the producer is the $\$ 1,950$ purchase price for the bred heifer. The producer estimates there will be no reduced returns (e.g., less genetic control, less control over disease). Subtracting total added costs $(\$ 1,950)$ from total added returns $(\$ 2,003.49)$ shows a net income increase of $\$ 53.49$ /replacement if the producer switches from raising to buying replacement heifers. Assuming 20 replacements are needed each year, the annual increase in net income for the farm is $\$ 802.41$.

The above analysis assumes a market return on surplus home-grown forages, operating capital, and opera- 
tor labor and management and no return on the existing investment in buildings, equipment, and facilities made available for use when heifers are no longer raised on the farm. To the extent these resources can be diverted to an alternative use (e.g., herd expansion) whose return exceeds these assumed levels, the analysis understates the economic benefits of buying heifers.

\section{BROKEN CRYSTAL BALL SYNTHESIS}

As economists who frequently give market situation and outlook presentations to cattle producers, we often are asked what our expectations are for the future on a host of issues facing the industry, and herd expansion is no different. The previous sections outlined economic factors that may restrict or support beef cow herd expansion. In this section we summarize our own expectations with a focus on general direction and net impacts of these economic considerations, rather than narrow precision and detail, to provide context on broader implications for the industry. These expectations can be outlined as follows.

The total U.S. beef cow herd will expand in coming years but the rate of expansion will underwhelm many in the industry when compared with past inventories. Although we view the most recent Food and Agricultural Policy Research Institute (2014) forecasts of limited expansion as too bearish, the USDA Economic Research Service (2014a) projections of a 2023 herd size of 33.7 million beef cows may also be more bullish on expansion than we are. We are more comfortable stating an expected herd size in $10 \mathrm{yr}$ between 31 and 33 million head.

This aggregate expansion forecast reflects an embedded expectation of continued beef demand growth. Narrowly, we are bullish that global beef demand growth will continue over the next decade. Although hiccups are bound to emerge, this demand growth serves a role of "pulling in more cows" in the form of derived demand for additional cattle supplies. Critically, if a larger (e.g., $\geq 33$ million) breeding herd is to materialize and be economically sustained, additional beef demand growth must be both appreciated and realized.

The regional distribution of the U.S. cow herd will continue to change but adjustments will be slow. Past assessments have highlighted how heifer retention patterns signal the herd is moving slowly to the north and west (Tonsor, 2014a). The BEEF Magazine 2014 survey and recent observations regarding cull cow marketing reinforce this trend and we expect it to broadly continue.

The cow-calf industry increasingly will become bimodal with a decreasing share of production from operations with 100 to 200 cows. This segment is less likely to have off-farm incomes (such as those with under 50 cows) supporting the cow-calf enterprise and yet does not fully realize economies of scale benefits of larger operations (McBride and Mathews, 2011). Given the increasing cost of production and associated profitability pressures that may return in coming years, we expect a continued "hollowing out" of mid-sized operations.

Related to this last point, we anticipate producers with lower production costs (who typically are also larger in herd size) to constitute a sizeable segment of net herd expansion and continue to constitute a larger share of overall calf crop production. Given differences in what can be paid for replacement females for a given targeted investment return, we expect this comparative advantage clearly to play out in the form of allocating replacements to operations with production cost advantages.

There will inevitably be significant turnover in production assets in the cattle industry in the coming years. Older producers who hold most of the equity increasingly will be involved in facilitating the transition to the younger generation. Leasing, contracting, and managerial arrangements may play a much bigger role in the future of the cattle business.

Innovation and creativity will emerge by a subset of producers facing land availability constraints who want to expand their operation. As economists, we are unable to envision what these alternative production systems may entail but given the substantial economic signals for expansion, we expect a portion of net herd expansion to occur as a result of producers adjusting from traditional "X cows per hectare" rules of thumb for their region by implementing adjustments allowing a net increase in management intensity and, hence, herd expansion on fewer total hectares than previously used.

\section{SUMMARY AND CONCLUSIONS}

The entire U.S. cattle industry is in the middle of several structural changes with pending (or perhaps ongoing) herd expansion at the heart of each current and possible industry adjustment. The net impacts of these adjustments will dictate the collective makeup of the U.S. cattle industry for years to come. The future size of the U.S. beef cow herd will be determined by the individual decisions of over 700,000 cattle owners (USDA NASS, 2014b). These owners are very diverse, not only in their physical operational characteristics and lifecycles but also in their perceptions and acceptance of the economic factors outlined in this article as impacting herd expansion. Where individual operations fall on this varied continuum will drive individual interest in expansion and, hence, directly impact the future composition of the U.S. cow-calf industry. Similarly, the aggregate industry's ability to recognize and act on the importance of ongoing beef demand growth is critical 
for the broader industry's ability to both expand the industry's size and improve overall economic well-being.

This article highlights a host of economic considerations that will underlie these individual decisions. Given the direct impact of this decision on the resulting size and economic viability of stakeholders throughout the vertically connected industry spanning from cow-calf producers to beef consumers, regularly monitoring this situation is of paramount importance. Individual producers are encouraged to make use of resources noted here and consult with the team of experts that you have assembled (e.g., beef extension specialist, herd health veterinarian, nutritionist, and lender) to guide their herd expansion decisions. Industry leaders and policymakers are encouraged to take note of the broader economic considerations outlined here as they form the foundation for the entire beef cattle industry's future viability. Finally, fellow researchers are encouraged, over time, to reassess points raised here, as the only thing constant is that things change and the need to regularly update the literature base of knowledge will persist.

\section{LITERATURE CITED}

Bobst, B. W., and J. T. Davis. 1987. Beef cow numbers, crop acreage, and crop policy. Am. J. Agric. Econ. 69:771-776. doi: $10.2307 / 1242187$.

Boggs, D., and E. Hamilton. 1997. Cow/calf analysis: Key indicators of profitability. In: Proc. Range Beef Cow Symp. XV, Rapid City, SD, December 9-11. p. 1-6.

Buhr, B. L., and H. Kim. 1997. Dynamic adjustment in vertically linked markets: The case of the U.S. beef industry. Am. J. Agric. Econ. 79:126-138. doi:10.2307/1243948.

Dhuyvetter, K., and K. Herbel. 2013. Differences between high-, medium-, and low-profit producers: An analysis of 2008-2012 Kansas farm management association cow-calf enterprise. http://www.agmanager.info/livestock/budgets/production/ beef/Cow-calf_EnterpriseAnalysis\%28Aug2013\%29.pdf. (Accessed 24 November 2014.)

Food and Agricultural Policy Research Institute. 2014. U.S. baseline briefing book: Projections for agricultural and biofuel markets. March 2014. FAPRI-MU Report \#02-14. http://www. fapri.missouri.edu/wp-content/uploads/2014/12/FAPRI_MU_ Report 02_14.pdf. (Accessed 24 November 2014.)

Langemeier, M. R., J. M. McGrann, and J. Parker. 2004. Beef cattle handbook: Economies of size in cow-calf production. BCH-8100. University of Wisconsin-Extension, Cooperative Extension.

Livestock Marketing Information Center (LMIC). 2014 Various spreadsheets accessed multiple times from August to November 2014. http://www.lmic.info/.

Marsh, J. M. 1999. The effects of breeding stock productivity on the U.S. beef cattle cycle. Am. J. Agric. Econ. 81:335-346. doi: $10.2307 / 1244585$.

McBride, W. D., and K. Mathews. 2011. The diverse structure and organization of U.S. beef cow-calf farms. Economic Information Bulletin Number 73, March 2011. U.S. Department of Agriculture, Economic Research Service, Washington, D.C.
Melton, B. E. 1980. Economics of beef cow culling and replacement decisions under genetic progress. West. J. Agric. Econ. 5:137-147.

Meyer, S., and L. Steiner. 2014. Daily livestock report. Vol. 12, No 63, March 28, 2014. http://www.dailylivestockreport.com/ documents/dlr\%2003-28-14.pdf. (Accessed 29 August 2014.)

Peel, D. S. 2014. Regional changes in cow-calf production: 2012 census of ag summary, Part 2. Cow/Calf Corner. The Newsletter from the Oklahoma Cooperative Extension Service. May 12, 2014. http://sunup.okstate.edu/category/ ccc. (Accessed 24 November 2014.)

Ramsey, R., D. Doye, C. Ward, J. McGrann, L. Falconer, and S. Bevers. 2005. Factors affecting beef cow-herd costs, production, and profits. J. Agric. Appl. Econ. 37:91-99.

Schmitz, J. D. 1997. Dynamics of beef cow herd size: An inventory approach. Am. J. Agric. Econ. 79:532-542. doi:10.2307/1244150.

Schroeder, T. C., G. T. Tonsor, and J. Mintert. 2013. Beef demand: Recent determinants and future drivers. http://www.beefboard.org/evaluation/130612demanddeterminantstudy.asp. (Accessed 24 November 2014.)

Tonsor, G. T. 2011. Evaluating cattle cycles: Changes over time and implications. http://www.agmanager.info/livestock/ budgets/production/beef/CattleCycleFact\%20Sheet_AMGTT-2011-4.pdf. (Accessed 24 November 2014.)

Tonsor, G. T. 2014a. A regional look at cattle herd trends. In the cattle markets. February 10, 2014. http://mic.info/publications/in-the-cattle-markets. (Accessed 24 November 2014.)

Tonsor, G. T. 2014b. Beef demand indices. http://www.agmanager.info/livestock/marketing/Beef\%20Demand/default.asp. (Accessed 24 November 2014.)

Tonsor, G. T., and K. C. Dhuyvetter. 2013. Net present values of beef replacements. http://www.agmanager.info/livestock/budgets/ production/beef/NPV\%20Replacement $\% 20$ Sensitivity $\% 20$ (Nov\%202013)_AM-GTT-KCD-2013.1.pdf. (Accessed 24 November 2014.)

U.S. Department of Agriculture, Animal and Plant Health Inspection Service (USDA APHIS). 2008. Beef 2007-08. Part I: Reference of beef cow-calf management practices in the United States, 2007-08. http://www.aphis.usda.gov/animal health/nahms/beefcowcalf/downloads/beef0708/Beef0708 dr_PartI_rev.pdf. (Accessed 24 November 2014.)

U.S. Department of Agriculture, Economic Research Service (USDA ERS). 2010. Cattle briefing room. http://www.ers.usda.gov/briefi ng/cattle/background.htm. (Accessed 24 November 2014.)

U.S. Department of Agriculture, Economic Research Service (USDA ERS). 2014a. Commodity costs and returns. http:// www.ers.usda.gov/data-products/commodity-costs-and-returns.aspx. (Accessed 24 November 2014.)

U.S. Department of Agriculture, Economic Research Service (USDA ERS). 2014b. USDA agricultural projections to 2023. http:// www.ers.usda.gov/publications/oce-usda-agricultural projections/ oce141.aspx\#.U867fPldW5I. (Accessed 24 November 2014.)

U.S. Department of Agriculture, National Agricultural Statistics Service (USDA NASS). 2014a. Cattle. http://usda.mannlib. cornell.edu/MannUsda/viewDocumentInfo.do?documentID $=1017$. (Accessed 24 November 2014.)

U.S. Department of Agriculture, National Agricultural Statistics Service (USDA NASS). 2014b. Census of agriculture. http:// www.agcensus.usda.gov/Publications/2012/\#full_report. Accessed 24-Nov-2014.

U.S. Meat Export Federation (USMEF). 2014. Frequently asked questions. https://www.usmef.org/about-usmef/faq/. (Accessed 24 November 2014.) 
Reproduced with permission of the copyright owner. Further reproduction prohibited without permission. 